Kumawula, Vol. 3, No.2, Agustus 2020, Hal 216 - 224

DOI: https://doi.org/10.24198/kumawula.v3i2.26491

ISSN 2620-844X (online)

Tersedia online di http://jurnal.unpad.ac.id/kumawula/index

\title{
Workshop Appreciative Inquiry dan Pelatihan Kewirausahaan untuk Membangun Etos Wirausaha Islam Pelaku UMKM Desa Cibodas Kabupaten Bandung
}

\author{
Hery Wibowo ${ }^{1 *}$, Bihayati Rusyidi ${ }^{2}$, Maulana $\operatorname{Irfan}^{3}$ \\ ${ }^{1,2,3}$ Departemen Ilmu Kesejahteraan Sosial Universitas Padjadjaran \\ Pusat Studi CSR, Kewirausahaan Sosial dan Pemberdayaan Masyarakat \\ *hery.wibowo@unpad.ac.id
}

\begin{abstract}
ABSTRAK
Praktik kewirausahaan secara umum terbangun dari dua hal yaitu pola pikir dan pola aksi. Pola pikir (etos) adalah hal yang melandasi lahirnya sebuah gerakan pantang menyerah, penuh kreativitas dan inovasi dalam membangun, mempertahankan dan mengembangkan usaha. Maka, beragam upaya membangun etos wirausaha yang berpotensi menghasilkan semangat juang tinggi, adalah sebuah investasi yang perlu diperjuangkan. Upaya membangun sebuah praktik usaha/kewirausahaan bukanlah sebuah pekerjaan yang mudah. Oleh karena itu, dibutuhkan sebuah cara pandang yang positif serta apresiatif, dan melibatkan anggota komunitas desa lainnya. Oleh karena itu, penting kiranya dilakukan sebuah program yang diharapkan dapat membangun pola pikir positif dan apresiatif bagi pelaku UMKM. Praktik kewirausahaan, dalam konteks Agama Islam masuk dalam ranah muamalah, yang harus dilakukan dengan cara mengikuti syariat Islam. Berdasarkan hal tersebut, maka dalam program ini workshop appreciative inquiry diparalelkan dengan pelatihan etos wirausaha Islami. Tulisan ini, secara umum akan memaparkan bagaimana pelaksanaan praktik pelatihan dan juga aktivitas Appreciative Inquiry dalam upaya membangun etos wirausaha pelaku UMKM di Desa Cibodas, Kecamatan Solokan Jeruk, Kabupaten Bandung Jawa Barat.
\end{abstract}

Kata kunci : Kewirausahaan, Pelatihan, UMKM, Appreciative Inquiry

\begin{abstract}
Entrepreneurial practice in general is built from two aspects, namely mindset and action patterns. The mindset (ethos) is the foundation of the birth of an unyielding movement, full of creativity and innovation in building, maintaining and developing a business. So, various efforts to build an entrepreneurial ethos that has the potential to generate high morale, is an investment that needs to be fought for. Efforts to build a business / entrepreneurial practice is not an easy job. Therefore, a positive and appreciative perspective is also needed, as well as the involvement of other members of the village community in order to build a conducive ecosystem. thus, it is important to carry out a program that is expected to be able to build a positive and appreciative mindset for SMEs. The practice of entrepreneurship, in the context of Islamic religion, falls within the realm of muamalah, which must be done by following Islamic law. Based on this, then in this program, the Appreciative Inquiry workshop was paralleled with an Islamic entrepreneur ethos training. This paper, in general, will explain how the implementation of training practices and also Appreciative Inquiry activities in an effort to build an entrepreneurial ethos of SMEs in Cibodas Village, Solokan Jeruk District, Bandung West Java Regency.
\end{abstract}

Keywords: entrepreneurship, appreciative inquiry, training, ethos 


\section{PENDAHULUAN}

Terminologi kewirausahaan secara umum mengacu pada kolaborasi pola pikir dan pola tindakan yang mendorong individu melakukan aksi kreatif dan inovatif yang disertai keberanian mengambil resiko. Maka, seorang wirausahawan adalah orang-orang yang memiliki jiwa wirausaha dan mengaplikasikan hakikat kewirausahaan dalam hidupnya (Zuhri, 2013). Secara umum, kewirausahaan dibangun melalui dua hal (Wibowo, 2009) yaitu pola pikir (etos) dan pola aksi (tindakan). Ray (dalam Harefa, 2010 dalam Wibowo, 2017) menjelaskan bahwa pola pikir (mindset) adalah segugusan keyakinan, nilai-nilai, identitas, ekspektasi, sikap, kebiasaan, opini dan pola pikir tentang individu, orang lain dan hidup. Sejumlah kajian lain menamakannya dengna sebutan etos. Maka etos, merupakan dasar atau daya dorong dari praktik wirausaha.

Secara umum etos dimaknai sebagai sikap kerja yang bersungguh-sungguh dan tidak mengerjakan sesuatu secara setengah-setengah (Tasmara, 2002). Maknanya, upaya membangun etos wirausaha merupakan sebuah usaha untuk menyuntikkan daya dorong yang besar sebagai energi untuk membangun, mempertahankan dan mengembangkan usahanya.

Satu hal penting yang perlu diperhatikan, khususnya bagi pelaku usaha di Desa, adalah terkait dengan isu perspektif atau cara pandang. Cara pandang akan mempengaruhi individu dalam melihat dan memaknai segala hal disekitarnya. Pendekatan problem based misalnya, mendorong individu untuk melihat beragam masalah yang harus diselesaikan. Berbeda dengan perspektif berbasis masalah, perspektif kekuatan lebih memfokuskan pada kekuatan dan sumber daya. Persepktif ini menyakin bahwa 'setiap orang, tanpa kecuali, mempunyai asset internal dan eksternal, kompetensi serta sumber daya (Saleeby, 2000 dalam Ishartono dkk, 2019).

Maka upaya membangun perspektif ini diyakini sebagai sesuatu yang penting untuk membangun kekuatan kolektif desa pada umumnya, dan secara khusus membangun kekuatan untuk membangun, mempertahankan dan mengembangkan usaha-usaha mandiri (UMKM).

Desa Cibodas Solokan Jeruk Kabupaten Bandung memiliki sejumlah UMKM berbasis masyarakat yang memiliki potensi untuk berkembang. Terdapat sejumlah UMKM yang berpotensi menjadi daya ungkit perekonomian desa, sekaligus merupakan usaha berbasis masyarakat lokal (sebagai solusi ketenagakerjaan) seperti telur asin, industri keset anyaman, bebek, olahan telur asin, kerajinan batok kelapa dan lain sebagainya 
Adapun definisi UMKM menurut Undang-Undang Nomor 20 tahun 2008 (dalam Noor dkk, 2016) adalah: Usaha Mikro adalah usaha produktif milik orang perorangan atau badan usaha yang memiliki kriteria sebagai berikut: (1) Memiliki kekayaan bersih paling banyak lima puluh juga tidak termasuk tanah dan bangunan tempat usaha, atau; memiliki hasil penjualan tahunan paling banyak 300 juta. Sedangkan Usaha Kecil adalah usaha ekonomi produktif yang berdiri sendiri, yang dilakukan oleh orang perorangan atau badan usaha yang bukan merupakan anak perusahaan atau bukan cabang perusahaan yang dimiliki, dikuasai atau menjadi bagian baik langsung maupun tidak langsung dari usaha menengah atau usaha besar yang memenuhi kriteria Usaha Kecil sebagai berikut: (1) Memiliki kekayaan bersih lebih dari lima puluh juta sampai paling banyak lima ratus juga, tidak termasuk tanah dan bangunan tempat usaha; atau (2) memiliki hasil penjualan tahunan lebih dari tiga ratus juta sampai paling banyak dua setengah milyar.

Dua dimensi penting dala membangun usaha (kewirausahaan) adalah pola pikir/etos dan pola tindakan (Wibowo, 2011). Pola pikir/asumsi dasar atau etos dalam hal ini merupakan daya dorong bagi pelaku usaha untuk mempertahankan dan mengembangkan usahanya. Secara teoritis, etos dimaknasi sebagai seperangkat perilaku kerja positif yang berakar pada kesadaran yang kental, keyakinan yang fundamental, disertai komitmen yang total pada paradigma kerja yang integral (Sinamo, 2005)

Maknanya, pelaku usaha perlu berangkat pondasi yang kokoh, termasuk dalam membangun niat usaha dan visi usahanya. Pola pikir kewirausahaan identic dengan kegigihan, keberanian untuk mengambil resiko, rasa urgenitas yang tinggi untuk selalu berkreasi, daya inovasi yang tinggi dan lain-lain (Wibowo \& Kudus, 2017)

Pada konteks muamalah Islam, hal ini dapat disebut sebagai akhlak. Adapun sejumlah akhlak usahawan muslim adalah niat yang tulus, budi pekerti luhur, usaha yang halal, menunaikan hak, menghindari ribah, menghindari mengambil harta orang lain dengan cara yang batil, menjaga komitmen terhadap peraturan dalam bingkai Undang-Undang Syariat, tidak memudharatkan orang lain, loyal kepada orang-orang beriman dan mempelajari hukumhukum mu’amalah Islam (ash-Shawi \& al Muslih, 2015)

Pada ilmu sosial, secara umum dikenal dua prespektif besar dalam memandang suatu fenomena. Atau dapat dikatakan bahwa perspektif dalam memandang kondisi masyarakat dapat dibagi dua, yaitu perspektif berbasis masalah (problem based), dan perspektif berbasis kekuatan (strength based).

Berbeda dengan perspektif berbasis masalah, perspektif berbasis kekuatan lebih memfokuskan pada kekuatan dan sumber daya. Perspektif ini meyakini bahwa "setiap orang, 
tanpa kecuali mempunyai asset internal dan eksternal, kompetensi, serta sumber daya (Dennis Saleebey; 2000 dalam Ishartono dkk, 2018). Maka, pandangan ini akan mendorong para pelakunya untuk berpikir dengan cara yang berbeda dan memandang dari arah yang berbeda.

Maka melalui pola pembinaan ini, diharapkan terbangu etos wirausaha yang kemudian dapat meningkatkan kualitas dan kuantitas praktik wirausaha di Desa Cibodas.

DIAGRAM 1.2 KERANGKA PEMIKIRAN

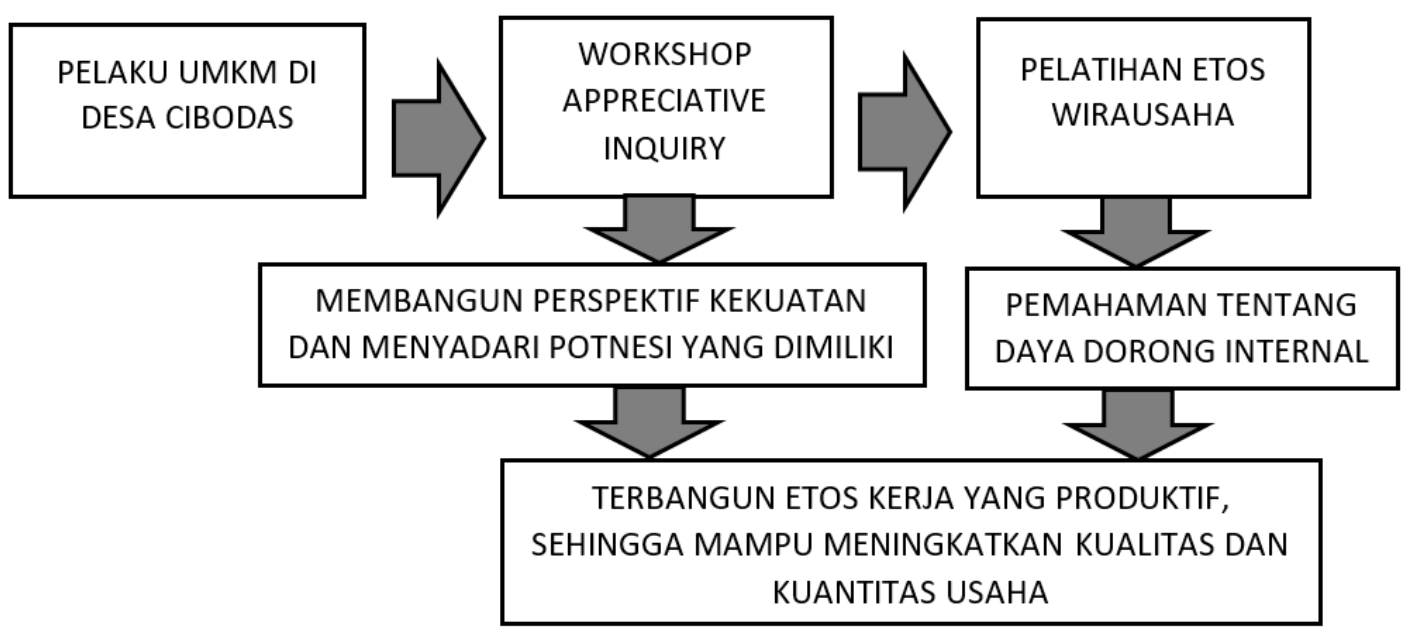

Etos kerja yang produktif, dalam ini merupakan komponen penting dalam membantu para pelaku usaha untuk mempertahankan dan mengembangkan usahanya. Sementara itu, pemahaman tentang prinsip-prinsip syariah, khususnya terkait Muamalah dalam berusaha/berbisnis juga merupakan hal tidak dapat diabaikan.

Perspektif atau mentalitas ini, merupakan dasar dari pengembangan pontesi yang dimiliki, dan merupakan pondasi dari pengembangan praktik kewirausahaan. Maka, penting kiranya ketika pemahaman ini disosialisasikan kepada lebih banyak pihak, khususny mereka yang sedang berfokus membangun wirausaha berbasis anggota masyarakatnya dan potensi wilayahnya

\section{METODE}

Praktik pengabdian ini berusaha mengadopsi sejumlah teknologi pembelajaran, agar mendapatkan hasil yang maksimal. Pada hakikatnya teknologi pembelajaran adalah suatu disiplin yang berkepeintingan dengan pemecahan masalah belajar dengan berlandaskan pada serangkain prinsip dan menggunakan berbagai macam pendekatan atau teori belajar dan pembelajaran (Isjoni, 2005:2-3 dalam Warsita, 2008) 
Pada kegiatan ini, metode utama yang digunakan adalah pelatihan dan workshop appreciative inquiry. Goldstsein dan Gressner (1988) mendefinisikan pelatihan sebagai usaha sistematis untuk menguasai keterampilan, peraturan, konsep, ataupun cara berperilaku yang berdampak pada peningkatan kinerja. Selanjutnya menurut Robert dan Dearden (1990) yang menyatakan bahwa pelatihan pada dasarnya meliputi proses belajar mengajar dan latihan bertujuan untuk mencapai tingkatan kompetensi tertentu atau efisiensi kerja.

Mathis \& John (2002:5), "Pelatihan adalah suatu proses dimana orang-orang mencapai kemampuan tertentu untuk membantu mencapai tujuan organisasi oleh karna itu, proses ini terikat dengan berbagai tujuan organisasi, pelatihan dapat dipandang secara sempit ataupun luas”. Fiedman dan Yarbrough (1985) menunjukan bahwa pelatihan adalah upaya pembelajaran, yang diselenggarakan oleh organisasi (instansi pemerintah, lembaga swadaya masyarakat, perusahaan, dan lain sebagainya) untuk memenuhi kebutuhan atau untuk mencapai tujuan organisasi.

Pendekatan apresiatif lebih berfikus pada penghargaan terhadap pencapaian, prestasi dan kekuatan yang ada, serta pengalaman terbaik yang pernah (terbukti) menentukan keberhasilan (Munir,2011).

Workshop Appreciative Inquiry adalah sebuah metode atau pendekatan perbaikan kinerja berbasis pola pikir apresiatif atau perspektif berbasis kekuatan.

Gambar 1: Siklus Appresiatif Inquiry

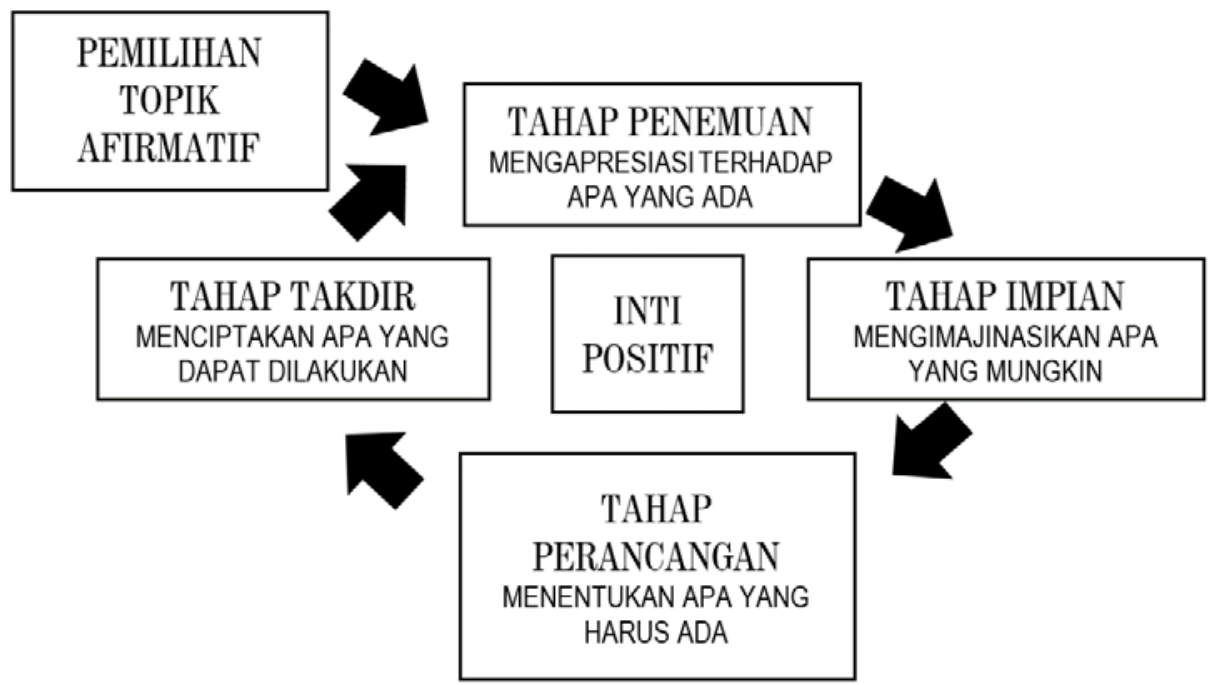

Dengan memperhitungkan organisasi yang berfungsi pada kondisi terbaiknya, Appreciative Inquiry membebaskan informasi dan komitmen untuk bersama-sama menciptakan energi bagi perubahan positif (Whitney \& Bloom, 2007). Adapun prosesnya dilakukan melalui siklus 4 D, yaitu Penemuan (Discover), Mimpi (Dream), Desain (Design) and Takdir (Destiny) 
Pada tahap Penemuan (Discover), peserta didorong untuk berpikir tentang kontribusi terbaiknya yang pernah dipersembahkan kepada masyarakat, khususnya masyarakat desa Cibodas. Hal ini untuk membangun kesadaran bahwa setiap orang, sekecil apapun, dapat memberikan kontribusi kepada Desa.

Selanjutnya pada tahap Mimpi (Dream), masyarat diajak untuk bervisi terkait kondisi yang Desa Cibodas lima tahun dari sekarang. Hal ini dimaksudkan untuk menanamkan rasa kecintaan yang lebih tinggi terkait Desa yang ditinggalinya, serta menguatkan harapan akan tercapainya kondisi desa yang lebih baik

Pada tahapan Desain (Design), seluruh peserta mulai merumuskan sejumlah langkah agar visi yang telah dicanangkan sebelumnya dapat tercapai, Proses dilakukan dengan berdiskusi, dengan pelibatan seluruh peserta.

Sedangkan tahap takdir (destiny) merupakan penguatan komtimen dalan sinergi dan kolaborasi untuk mencapai target yang dicanangkan.

Seiring dengan pendekatan berbasis kekuatan ini, Graybeal (2001 dalam Raharjo dan Wibowo, 2019) mengusulkan penggunaan ROPES (Resources, Option, Possibilities, Exeception \& Solution) dalam melakukan asesmen yang berbasis kekuatan. Model ini dimaksudkan untuk mendorong lahirnya pemikiran-pemikiran yang bersumber dari kekuatan yang telah dimiliki.

\section{PEMBAHASAN}

Proses Pelatihan dan Workshop Appreciative Inquiry dilakukan secara bertahap, yaitu diawali dengan pelatihan etos wirausaha Islami dan diakhiri diskusi kelompok terpimpin. Peserta dapat mengikuti sesi yang disajikan dengan baik.

Adapun materi Etos Wirausaha yang diberikan merujuk pada tulisan tentang akhlak usahwan muslim (ash-Shawi \& al-Muslim, 2015) . Berikut adalah sejumlah akhlak (pola pikir dan pola tindakan yang perlu diperhatikan ketika melakukan praktik wirausaha adalah (1) Niat yang tulus, (2) Budi Pekerti Luhur, (3) Usaha yang Halal, (4) Menunaikan Hak, (5) Menghindari Riba dan Segala Sarana Riba Seperti Transaksi-transaksi kotor, (6)Menghindari Mengambil Harta Orang lain dengan cara batil (7) Menjaga komitmen terhadap peraturan dalam bingkai Undang-Undang Syariat, (8) Tidak memudaratkan orang lain, (9) Loyal kepada orang-orang Beriman dan (10) Mempelajari Hukum-Hukum Mu’amalah Islam.

Adapun tujuan umum dari pemberian materi ini adalah mengenalkan dasar-dasar muamalah Islam kepada para pelaku Usaha Kecil Menengah, agar secara perlahan-lahan mampu 
memposisikan usahanya pada jalur yang benar. Etos wirausaha yang berbasis pemahaman Islam itu sendiri, diharapkan akan menjadi daya dorong bagi para pelaku usaha, menjalankan usahanya berbasis pemahaman syariah.

Setelah mengikuti pelatihan dan workshop appreciative inquiry maka sedikit demi sedikit terkumpul sejumlah harapan dan komitmen dari para peserta, seperti yang ditampilkan dalam tabel dimuka. Hal ini tentu merupakan sebuah modal berbentuk semangat juang baik untuk memajukan usahanya maupun untuk membangun desanya.

\section{Tabel 1.1}

\section{Hasil Diskusi dalam Appreciative Inquiry}

\begin{tabular}{|c|c|c|c|c|}
\hline Kel & Discover & Dream & Desa in & Destiny \\
\hline 1 & 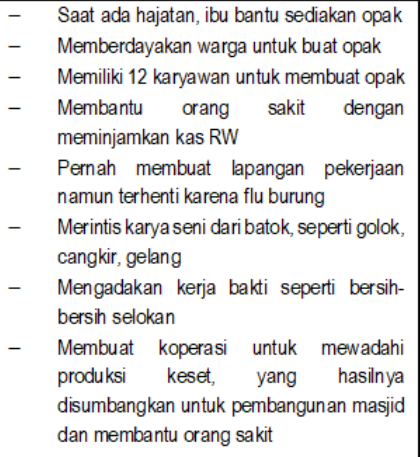 & $\begin{array}{ll}\text { - } & \text { Kemiskinan berkurang } \\
- & \text { Ekonomi meningkat } \\
\text { - } & \text { Usaha lebih maju } \\
- & \text { Lebih muda melakukan usaha di Desa Cibodas } \\
- & \text { Pengangguran berkurang } \\
- & \text { Warga selalu sehat } \\
- & \text { MCK rumah yang tidak layak huni dapat } \\
& \text { diperbaiki } \\
- & \text { Pengajaran agama dan pengajian lebih } \\
& \text { ditingkatkan } \\
- & \text { Air lebih bersih } \\
- & \text { Pegawai desa harus turun ke masyarakat dan } \\
- & \text { berangkat pengajian } \\
- & \text { Bank sampah diefektifkan } \\
- & \text { Pengelolaan sawah ditingkatkan }\end{array}$ & 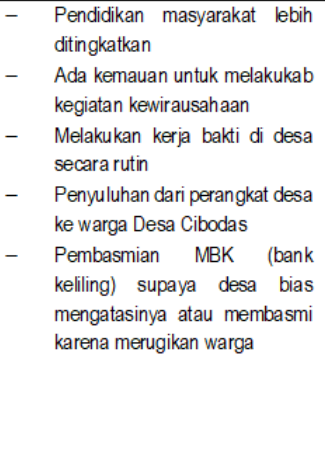 & 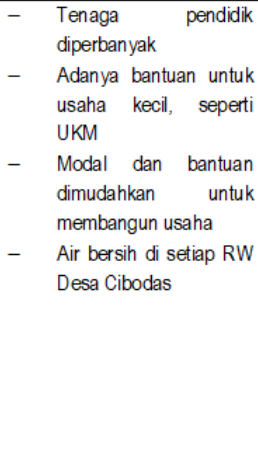 \\
\hline 2 & 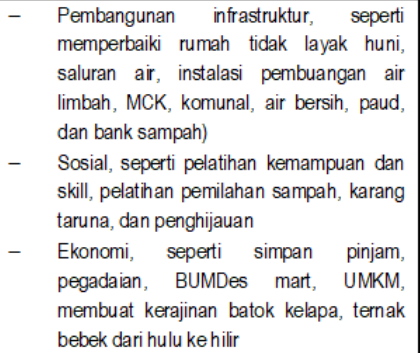 & $\begin{array}{ll}- & \text { Kemiskinan berkurang } \\
- & \text { Ekonomi sudah maju } \\
- & \text { Infrastruktur sudah bagus semua } \\
- & \text { Semakin berdaya bidang kewirausahaannya } \\
- & \text { Sejahtera rakyatnya } \\
- & \text { Pola piker SDM Cibodas sudah maju } \\
- & \text { Masyarakat sadar akan sampah } \\
- & \text { Menjadi desa yang zero waste } \\
- & \text { Menjadi desa pelopor dari berbagai bidang }\end{array}$ & $\begin{array}{ll}- & \text { Pelatihan dan sosialisasi } \\
- & \text { Tindakan } \\
- & \text { Kebersamaan } \\
\text { - } & \text { Menemukan sumber masalah }\end{array}$ & $\begin{array}{llr}\text { - } & \begin{array}{l}\text { Orang-orang yang } \\
\text { berkompeten }\end{array} \\
& \text { bidangnnya } \\
\text { - } & \text { Ada mediapartner } \\
- & \text { Masyarakat dan } \\
& \text { pemerintah yang } \\
& \text { sinergis } \\
\text { - } & \begin{array}{l}\text { Penjualan secara door } \\
\text { to door }\end{array} \\
\text { - } & \begin{array}{l}\text { Adanya modal dan } \\
\text { bantuan usaha }\end{array}\end{array}$ \\
\hline 3 & 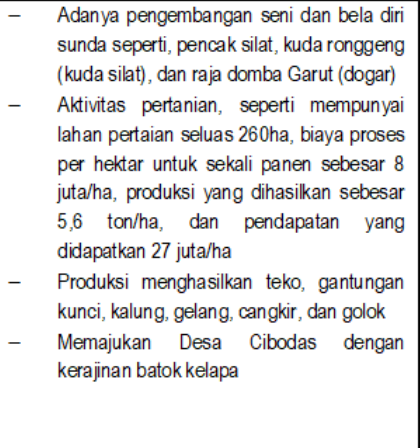 & $\begin{array}{ll}\text { - } & \text { Desa menjadi agamis, mandiri, dan akademis } \\
\text { - } & \text { Lebih maju dalam bidang pengairan secara } \\
\text { tekis untuk meningkatkan hasil produksi di } \\
\text { bidang pertanian } \\
\text { - } \quad \text { Mempermudah pendistribusian secara mandiri, } \\
\text { terkelola dengan perekonomian yang ada di } \\
\text { Desa Cibodas } \\
\text { - } \quad \text { Produksi ternak meningkat dan pemasaran } \\
\text { lebih mudah } \\
\text { - Mengurangi jumlah pengangguran dan } \\
\text { meningkatkan seni budaya yang lebih maju, dan } \\
\text { mengajak anak muda lebih kreatif di Desa } \\
\text { Cibodas } \\
\text { Memajukan kerajinan dan kesenian di Desa } \\
\text { Cibodas }\end{array}$ & 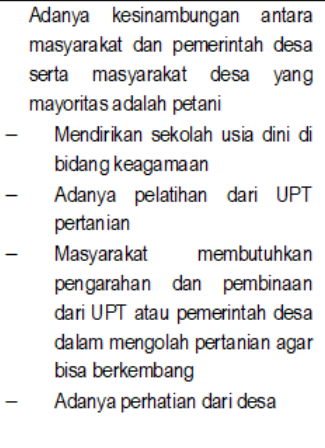 & - $\quad$ Banyak tenaga ahli \\
\hline
\end{tabular}

Berikut ringkasan hasil pemikiran peserta ketika dan setelah mengikuti workshop.

Berbasis tabel dimuka, terungkap hal-hal yang dipikirkan dan dirasakan oleh masyarakat. Gerak hati masyarakat terungkap antara lain melalui visi mereka yang sama-sama ingin 
membangun desa, mengoptimalkan seluruh potensi, mendorong kemajuan usaha dan lain-lain. Perspektif positif dan apresiatif yang dicoba ditawarkan, tampak sudah mulai mempengaruhi pemikiran warga. Hal ini terlihat dari respon warga yang mampu dengan baik menuliskan harapannya, visinya serta sejumlah rencana yang ingin mereka lakukan untuk membangun usaha mandirinya secara khusus dan mengembangkan desanya secara umum.

Melalui pemahaman yang baik tentang potensi desa, khususnya potensi masyarakat desa, maka diharapkan sebanyak mungkin warga desa dapat berpatisipasi membangun desa. Selanjutnya, melalui kesadaran bahwa setiap orang memiliki potensi (dalam bentuk apapun) untuk pembangunan desa, seyogianya, kesadaran untuk berkontribusi menjadi lebih meningkat ke seluruh warga desa, termasuk para pengusaha/pelaku UMKM.

Program ini, diharapkan dapat memberikan sedikit kontribusi bagi para pelaku UMKM pada khususnyanya dan potensi kewirausahaan desa pada umumnya.

Kesimpulan

1. Workshop Appreciaty Inquiry telah berhasil mengumpulkan sejumlah pelaku usaha dan tokoh masyarakat untuk duduk dan berpikir bersama tentan

2. Upaya membangun pola pikir positif/pendekatan apresiatif pada pelaku UMKM telah secara bertahap mendorong terbangunnya cara pandang baru terhadap potensi yang dimiliki, baik potensi yang berkaitan dengan kegiatan usaha pada khususnya dan pada sumber daya desa pada umumnya

3. Pemahaman tentang etos wirausaha Islam, dapat menambah pemahaman yang baik tentang apa dan bagaimana seharusnya visi berwirausaha, sehingga para pelaku usaha terhindari dari melakukan hal-hal yang dilarang oleh syariat.

\section{DAFTAR PUSTAKA}

Anthony, Robert N, dan John Dearden, 1990, “Sistem Pengendalian Manajemen”, Ali Bahasa Agus Maulana, Erlangga, Yogyakarta

Ash-Shawi, Shalah \& Al-Muslih, Abdullah. 2015. Fikih Ekonomi Islam: Cetakan Kelima. Jakarta. Penerbi Darul Haq

Fiedman, P.G., dan Yarbrough. 1985. Training Strategi From Start To Finish, Ne Jersey: Prentice Hall.Inc., Engelwood Cliffs Hall. 
Goldstein dan Gressner. (1988). Sumber Daya Manusia dan Produktivitas Kerja. Bandung: Mandar Maju.

Ishartono: Raharjo, Tri Raharjo \& Rusyidi, Binahayati. 2018. Kekuatan Keluarga Miskin (Strenght Perspective). Cetakan Pertama. Bandung. ITB Press.

Mathis Robert, Jackson John. 2002. Manajemen Sumber Daya Manusia. Jakarta : Salemba empat

Munir, Risfan. 2011. Manajemen Apresiatif: Melejitkan Potensi Diri Dalam Karir dan Bisnis Melalui Sikap Menghargai. Cetakan Pertama. Bandung. Penerbit Kaifa Mizan Pustaka

Noor, Deiky Lutfiansyah; Wibowo, Hery \& Zainuddin, Muhamad. 2016. Pemberdayaan UMKM. Jatinangor-Sumedang. Penerbit Unpad Press

Santoso, Tri Raharjo \& Wibowo, Hery. 2019. Belajar “Bersama” dari dan untuk Masyarakat Desa. Jatinangor-Sumedang. Penerbit Niaga Muda Press.

Sinamo, Jansen H. 2005. 8 Etos Kerja Profesional. Cetakan Pertama. Jakarta. Penerbit Institut Darma Mahardika

Tasmara, Toto. 2004. Membudayakan Etos Kerja Islami.Cetakan ketiga. Jakarta. Penerbit Gema Insani

Warsita, Bambang. 2008. Teknologi Pembelajaran. Cetakan pertama. Jakarta. Penerbit Rineka Cipta

Whitney, Diana \& Trosten-Bloom, Amanda \&. 2007. The Power of Appreciative Inquiry: 4 Perubahan Positif dalam Organisasi. Cetakan Pertama. Yogyakarta. Penerbit B-First.

Wibowo, Hery \& Kudus Imanudin. 2017. Pekerjaan Sosial, Kewirausahaan Sosial dan Pendidikan Tranformatif. Sumedang-Jawa Barat. Penerbit Unpad Press

Wibowo, Hery. 2011. Kewirausahaan: Suatu Pengantar. Cetakan pertama. Bandung. Penerbit Widya Padjadjaran.

Wibowo, Hery. 2017. Kewirausahaan Sosial \& Pembangunan Sosial. Cetakan Pertama. Jatinangor-Sumedang. Penerbit Unpad Press

Zuhri, Nase Saefudin. 2013. Kewirausahaan: Kajian Perspektif Umum dan Islam. Cetakan Pertama. Bandung. Plater Mega Kreasi 
